\title{
TRADISI MABBACA DOANG MASYARAKAT SUKU BUGIS KELURAHAN KABONENA KECAMATAN ULUJADI KOTA PALU
}

\author{
Erni Irmayanti Hamzah \\ Dosen Fakultas Tarbiyah dan Keguruan IAIN Palu \\ erni_irmayantiH@iainpalu.ac.id
}

\section{Abstract}

This study aims to find out 1) why the Bugis people in the Kabonena Village, Ulujadi District, Palu City carry out the Mabbaca Doang Tradition. 2) the meaning of Mabbaca Doang to the Bugis people in the Kabonena Village, Ulujadi District, Palu City. 3) the function of Mabbaca Doang in the Bugis community in Kabonena Village, Ulujadi District, Palu City. This type of research uses qualitative research with descriptive analysis. Data collection techniques were carried out using observation, interviews, and documentation methods by involving five individual informants. Based on the results of the study, it shows that: 1. The local Bugis community carries out the mabbaca only tradition in the Bugis Tribe community in the Kabonena Village, Ulujadi District, Palu City, namely because mabbaca only is considered an ancestral heritage that deserves to be maintained because the process is not so burdensome and the intention is because of Allah and if only this mabbaca is not done, they believe that something will happen to their life. 2. The meaning of mabbaca only for the Bugis people of the Bugis people in the Kabonena Village, Ulujadi District, Palu City, namely the first as a form of gratitude to God and the second as a repellent against reinforcements. 3. The function of mabbaca only for the Bugis people in the Kabonena Village, Ulujadi District, Palu City, namely as a religious embodiment that contains individual beliefs about what God has given him and intensifies social solidarity.

Keywords: tradition mabbaca doang, social solidarity, bugis tribe community.

\section{Abstrak}

Penelitian ini bertujuan untuk mengetahui 1) mengapa masyarakat Suku Bugis di Kelurahan Kabonena Kecamatan Ulujadi Kota Palu melakukan Tradisi Mabbaca Doang. 2) makna Mabbaca Doang terhadap masyarakat Suku Bugis di Kelurahan Kabonena Kecamatan Ulujadi Kota Palu. 3) fungsi MabbacaDoang pada masyarakat Suku Bugis di Kelurahan Kabonena Kecamatan Ulujadi Kota Palu. Jenis penelitian ini menggunakan penelitian kualitatif dengan analisis deskriptif. Teknik pengumpulan data dilakukan dengan menggunakan metode observasi, wawancara, dan dokumentasi dengan melibatkan individu sebanyak lima orang informan. Berdasarkan hasil penelitian menunjukkan bahwa : 1 . Masyarakat su k u B u g is setempat melakukan tradisi mabbaca doang di masyarakat Suku Bugis di Kelurahan Kabonena Kecamatan Ulujadi Kota Palu 
yaitu karena mabbaca doang dianggap sebagai warisan leluhur yang layak untuk dipertahankan karena prosesinya yang tidak begitu memberatkan dan niatnya karena Allah dan jika mabbaca doang ini tidak dilakukan, mereka percaya bahwa akan ada sesuatu hal yang akan menimpa hidup mereka. 2. Makna mabbaca doang bagi masyarakat Suku Bugis masyarakat Suku Bugis di Kelurahan Kabonena Kecamatan Ulujadi Kota Palu yaitu pertama sebagai bentuk rasa syukur kepada Tuhan dan yang kedua sebagai penolak bala. 3. Fungsi mabbaca doang bagi masyarakat Suku Bugis di Kelurahan Kabonena Kecamatan Ulujadi Kota Palu yaitu sebagai perwujudan religi yang berisi tentang keyakinankeyakinan individu terhadap apa yang telah diberikan Tuhan kepadanya dan mengintensifikasikan solidaritas sosial.

Kata kunci : tradisi mabbaca doang, solidaritas social, masyarakat suku bugis.

\section{PENDAHULUAN}

Kebudayaan merupakan persoalan yang sangat komplek dan luas, misalnya kebudayaan yang berkaitan dengan cara manusia hidup, adat istiadat dan tata krama. Kebudayaan sebagai bagian dari kehidupan, cenderung berbeda antara satu suku dengan suku lainnya, khususnya di Indonesia. Masyarakat Indonesia yang heterogen juga adat istiadat dan kebiasaannya yang berbeda dan masih dipertahankan sampai saat ini.

Keanekaragaman budaya yang dimiliki bangsa Indonesia yang senantiasa dijaga dan dilestarikan secara turun-temurun adalah merupakan gambaran kekayaan bangsa Indonesia menjadi modal dan landasan pembangunan dan pengembangan kebudayaan nasional. Pengembangan kebudayaan nasional berarti memelihara, melestarikan, menghadapkan, memperkaya, menyebarluaskan, memanfaatkan, dan meningkatkan mutu serta daya guna kebudayaan. Manfaat yang dihasilkan dalam kebudayaan itu sendiri adalah dalam melangsungkan kehidupan. ${ }^{1}$

Masyarakat Indonesia adalah masyarakat majemuk yang memiliki bermacammacam kebudayaan dan adat-istiadat yang hidup dalam kesatuan sosial, dengan kemajemukkan itulah yang menimbulkan banyak perbedaan-perbedaan suku, ras, memperkaya khasanah budaya masyarakat Indonesia. Adat-istiadat dan tradisi ini mih berlaku dalam lingkungan masing-masing etnis. Kenyataan menunjukkan bahwa kebudayaan masyarakat Indonesiatelah tumbuh dan berkembang sejak ribuan tahun lalu. Hal ini merupakan warisan para leluhur bangsa Indonesia yang masih dilaksanakan oleh masyarakat Indonesia dan selalu mewarnai kehidupan masyarakat dimasa sekarang. ${ }^{2}$

Setiap daerah memiliki budaya lokal tersendiri dan merupakan identitas bersama pada masyarakat setempat. Salah satu aspek yang nampak dalam kebudayaan lokal adalah tradisi dan adat istiadat. Sistem nilai budaya merupakan tingkat yang paling

1Natali Juli, "Hakikat Kebudayaan Nasional", Blog Natali Yuli. http: //Pendidikan.blogspot.com/2013/11 / hakikat-kebudayaan-nasional-dalam.html. pada tanggal 23 April 2020 pukul 14.12 WIB.

2 Omi Sastra, "Tradisi Pantauan Pengantin Di Desa Alam Lama Kecamatan Kota Agung Kabupaten Lahat", skripsi, (Palembang: Fakultas Adab dan Humaniora, UIN Raden Fatah Palembang), 2017. 1 
tinggi dan paling abstrak dari adat istiadat. Hal itu disebabkan karena nilai budaya merupakan konsep-konsep m engenai sesuatu yang ada dalam alam pikiran sebagian besar dari masyarakat yang mereka anggap bernilai, berharga dan penting dalam hidup sehingga dapat berfungsi sebagai suatu pedoman yang memberi arah dan orientasi pada kehidupan pada warga masyarakat tadi.

Bugis adalah salah satu suku yang dikenal dengan kekentalan budaya dan adat istiadatnya. Sebagian besar masyarakatnya masih tetap melestarikan budaya leluhurnya hingga saat ini. Budaya tersebut berupa kesenian, bahasa, sistem kemasyarakatan, serta budaya-budaya lokal lainnya yang mempunyai nama tersendiri di tiap daerah yang ada di Sulawei Selatan. Salah satu daerah yang didiami oleh suku Bugis adalah kota palu.

Masyarakat Kota Palu sangat heterogen. Penduduk yang menetap di kota ini berasal dari berbagai suku bangsa seperti Bugis, Toraja, dan Mandar yang berasal dari Sulawesi Selatan dan Sulawesi Barat, Gorontalo, Manado, Jawa, Arab, Tionghoa, dan Kaili yang merupakan suku asli dan terbesar.

Tradisi masyarakat suku bugis tetap dipertahanjan meskipun kebiasaan mereka sudah terpola dengan masyarakat asli sulawesi tengah. Salah satu budaya lokal yang tetap menjadi tradis masyarakat bugid di kota palu adalah mabbaca doang.

Mabbaca dalam bahasa Indonesia artinya membaca sedangkan Doang artinya yakni doa. Jadi dapat disimpulkan Mabbaca Doang adalah proses pembacaan doa. Tapi tradisi ini tidak seperti prosesi pembacaan doa pada umumnya. Doa dalam tradisi Mabbaca Doang dibacakan oleh sang Guru, yakni orang yang dipercaya di sebuah daerah/kampung untuk membawakan doa. Biasanya beliau seorang Imam mesjid setempat, khatib, ustas, pemuka adat atau orang yang dihormati di daerah tersebut.

Secara umum Mabbaca Doang hanya dilaksanakan pada saat-saat tertentu saja, yakni ketika seseorang diannggap mampu secara materi sehingga dapat menyajikan menu-menu baca doang kemudian mengundang masyarakat untuk berkumpul bersamasama guna menjalin silaturahmi serta melantunkan doa bersama. Ikatan sosial atau kohesi sosial sangat nampak pada tradisi ini, kerena mereka bekerja sama mempersiapkan menu-menu, biasanya ini dilakukan oleh para ibu-ibu sedangkan lakilaki biasanya melakukan tugas lapangan seperti mendatangi satu persatu rumah warga untuk mengundangnya menghadiri acara Mabbaca Doang tersebut.

Masyarakat di sana masih rutin melaksanakan tradisi Mabbaca Doang. Seiring perkembangan zaman tradisi ini tetap dipertahankan meskipun banyak pertentangan yang terjadi di tengah-tengah masyarakat karena adanya dupa, kemenyan, dan makananmakanan khusus yang disediakan. Dalam observasi awal yang penulis temukan dilapangan bahwa acara mabbaca doang rutin dilakukan oleh masyarakat setempat apalagi pada saat atau setelah lebaran mereka biasanya berbondong-bondong mempersiapkan semua keperluan dan menyediakan semua makanan yang akan dihidangkan untuk melakukan tradisi Mabbaca Doang.

\section{TINJAUAN PUSTAKA}

\section{Pengertian Tradisi}

\footnotetext{
${ }^{3}$ Koentjaraningrat. 2015. Pengantar Ilmu Antropologi. Jakarta: Rineka Cipta., 153
} 
Secara etimologi atau studi kata, kata tradisi dalam bahasa Indonesia berasal dari bahasa Inggris, tradition. Seperti kata action, connection, resolution atau justification, dalam bahasa Inggris, sufiks atau akhiran "-tion" pada kata tradition diganti dengan akhiran "-si" sehingga menjadi tradisi. Namun sebenarnya akar kata tradisi atau tradition itu sendiri berasal dari bahasa Latin, traditio; dan traditio adalah kata benda dari kata kerja tradere atau traderer, yang bermakna "menyampaikan, menyerahkan untuk mengamankan, atau mentransmisikan", atau dengan kata lain, tradisi adalah "sesuatu yang ditransmisikan". ${ }^{4}$

Tradisi menurut kamus besar bahasa Indonesia adalah segala sesuatu seperti adat, kepercayaan, kebiasaan ajaran dan sebagainya yang turun-temurun dari nenek moyang. Sejarah menyajikan fakta bahwa tradisi sebagai salah satu ekspresi budaya dalam mempertahankan denyut nadi kehidupannya kadang tarik menarik denganagama formal. Setiap agama maupun tradisi hampir dimungkinkan menghadapi problema perbenturan diantara keduanya. Agama-agama formal menurut Istilah R. Redfild disebut great tradition sering kali diperhadapkan vis a vis dengan budaya lokal (little tradition).

Tradisi menjadi bagian dari hasil kreasi manusia dalam mengembangkan potensi yang dimilikinya sebagai mahkluk ciptaan Allah Swt. di muka bumi. Dalam menjalankan fungsinya sebagai khalifah manusia mengatur kehidupannya berdasarkan aturan dari agamanya demi terwujudnya hidup yang diridhai-Nya, menjalin hubungan dengan sesama makhluk berdasarkan petunjuk dan tuntunan agama sehingga segala bentuk aktivitasnya baik berupa adat-istiadat, norma, kebiasaan atau tradisi harus sejalan dengan syari'at

\section{Mabbaca Doang}

Mabbaca dalam bahasa Indonesia artinya membaca sedangkan Doang artinya yakni doa. Jadi dapat disimpulkan Mabbaca Doang adalah proses pembacaan doa. Tapi tradisi ini tidak seperti prosesi pembacaan doa pada umumnya. Doa dalam tradisi Mabbaca Doang dibacakan oleh sang Guru, yakni orang yang dipercaya di sebuah daerah/kampung untuk membawakan doa. Biasanya beliau seorang Imam mesjid setempat, khatib, ustas, pemuka adat atau orang yang dihormati di daerah tersebut.

Secara umum Mabbaca Doang hanya dilaksanakan pada saat-saat tertentu saja, yakni ketika seseorang diannggap mampu secara materi sehingga dapat menyajikan menu-menu baca doang kemudian mengundang masyarakat untuk berkumpul bersamasama guna menjalin silaturahmi serta melantunkan doa bersama. Ikatan sosial atau kohesi sosial sangat nampak pada tradisi ini, kerena mereka bekerja sama mempersiapkan menu-menu, biasanya ini dilakukan oleh para ibu-ibu sedangkan lakilaki biasanya melakukan tugas lapangan seperti mendatangi satu persatu rumah warga untuk mengundangnya menghadiri acara Mabbaca Doang tersebut.

Mabbaca doang dalam konsep perubahan sosial seiring berjalannya waktu telah mengalami kesenjangan sosial. Perubahan unsur-unsur dalam tradisi Mabbaca doang tidak dapat dihindari sehingga akan ada dampak pada pola kehidupan masyarakat setempat. Unsusr-unsur tersebut adalah nilai-nilai dari tradisi Mabbaca doang. Perubahan nilai atau

\footnotetext{
${ }^{4}$ Muhammad Ali, Kamus Lengkap Bahasa Indonesia Modern (Jakarta: Pustaka Amani), 13
} 
unsur sebuah tradisi dalam perubahan sosial merupakan hal yang tidak bisa terhindarkan.

Nilai adalah suatu bagian penting dari kebudayaan. Suatu tindakan dianggap sah, artinya secara moral dapat diterima kalau harmonis dengan nilai-nilai yang disepakati dan dijunjung oleh masyarakat dimana tindakan itu dilakukan. Didalam masyarakat yang terus berkembang, nilai senntiasa akan ikut berubah. Pergeseran nilai dalam banyak hal juga kan mempengaruhi perubahan folkways dan mores. ${ }^{5}$

Asal mula tradisi Mabbaca Doang pada masyarakat kelurahan Benteng Sawitto Kecamatan Paleteang Kabupaten Pinrang, yakni beriringan pencerahan Islam masuk di Sawitto atas pelopor wali bernama Tumpakki. Makna utama dari prosesi Mabbaca Doang yakni berdoa kepada Allah SW'T atas kesyukuran dan Tulabala (Tolak Bala). Pelaksanaannya merupakan sebuah nilai yang dituangkan melalui cara pelaksanaan. Proses Mabbaca Doang hanyalah cara, sedangkan tujuannya adalah berdoa. Maka dari itu tidak salah jika masyarakat memaknainya sebagi satu kesatuan yang tidak dapat dipisahkan, ketika ada proses berdoa maka ada orang yang berkumpul untuk duduk dan makan bersama. Itulah nilai yang dianggap sah pada masyarakat Sawitto tentang tradisi Mabbaca Doang.

Adapun cara yang dilakukan masyarakat, yakni mempersiapkan makanan, dupa, memanggil Guru/Katte serta memenuhi aturan-aturan yang sering dikonsumsi terkait Baca Doang tidak lain adalah bentukan masyarakat pendahulu dan akhirnya tetap dijalankan hingga sekarang. Tidak ada hukum wajib dalam pelaksanaanya hanya saja untuk pelestarian budaya dan kebiasaan masyarakat setempat. Makna atau nilai sesunggunhya dari tradisi Mabbaca doang bukan karena proses atau cara yang digunakan dalam pelaksanaannya namun bagaimana niat berdoa yang dipanjatkan kepada Tuhan..

Dalam pelaksanaan tradisi Mabbaca Doang tentu tidak akan sama seperti dulu. Menyimak pengakuan bebebrapa informan, tradisi Mabbaca Doang ini masih kita jumpai sampai sekarang bahkan jika dilihat tidak akan hilang. Namun, karena perkembangan zaman akibat perubahan sosial, tentunya ada perubahan dalam aspek ikatan sosial dalam hal ini kohesi sosial.

Kohesi sosial yang berubah tidak menyentuh segala perubahan ikatan pada masyarakat, melainkan hanya berbagai aspek saja seperti berkurangnya kerjasama dala upaya mempersiapkan acara Mabbaca Doang, lengsernya kebiasaaan interaksi langsung dalam mengundang, interaksi yang berlangsung hanya sebentar saja serta masyarakat cenderung hadir dalam sebuah acara Mabbaca Doang jika mereka merasa dalam keadaan tidak beratifitas.

Dengan adanya perkembangan pola pikir masyarakat, tradisi ini tetap dilaksanaknan namun mengubah arti-arti yang tidak bisa dilogikan oleh nalar serta tidak membuat aturan yang ketat dalam pelaksanaanya agar tradisi ini tetap lestari tanpa membebabnkan masyarakat. Tradisi Mabbaca Doang secara temurun tetap terlasana hingga menembus era modern sekarang ini. Adapun yang berubah yakni adanya

${ }^{5}$ Narwoko, Dwi, dan Bagong Suyanto. Sosiologi Teks Pengantar dan Terapan Cet. III; Jakarta: Kencana, 2007. 55 
pergeseran nilai. Adapun nilai yang berubah yakni nilai-nilai yang masih tradisional seperti mengedepankan unsur mitos, mistik dan pamali itu sudah dihilangkan, sekarang yang menjadi sorotan utama adalah pelaksanaan baca doang merupakan usaha pelestarian budaya saja. Masyarakat melaksanakannya karena tardisi turun temurun bukan karena yang lain.

Tradisi Mabbaca Doang tidak melihat dasar apakah orang kaya atau miskin melainkan kesanggupan orang yang akan melaksanakan. Tidak ada paksaan harus ramai atau harus dihadiri banyak orang melainkan bagaimana niatnya. Sah-sah saja jika acara Mabbaca Doang meriah asalakan pemilik acara sanggup dan sebailknya tidak ada larangan jika sederhana karena dalam pelaksanaan tradisi Baca Doang tidak harus mempersiapkan banyak makanan, mengundang banyak tamu namun dasar dari tradisi ini adalah niatnya untuk memanjatkan doa kepada Tuhan.

Mabbaca Doang dalam perspektif agama mempunya arti yang beragam dalam kacamata paham-paham dan aliran dalam Islam. Hal itu adalah hal yang tidak bisa dipadukan karena semua masyarakat punya alasan kuat tersendiri. Sebagian besar masyarakat masih melaksanakannya karena tidak bertentangan dengan pahamnya tetapi tidak sedikit yang meninggalkannya karena adanya pengetahuan lebih akan agama. Tidak ada yang salah dalam Islam selama masih untuk kebaikan bersama.

Benang merah yang dapat kita tarik dari penelitian ini terkait dengan teori struktural fungsianal Robert King Merton yakni konsep fungsional dan disfungsional adalah tradisi mabbaca doang masih eksisi sampai sekarang itu karena masih dianggap fungsional bagi sebagian besar masyrakat Kelurahan Benteng Sawitto Kecamatab Paleteang Kabupaten Pinrang baik itu dalam segi niat maupun pel;aksanannya. Akan tetapi sebaian masyarakat menggap disfungsional keran tidak sesuai dengan keyakinan, niat dan pola kehdupan masyaraat.

\section{Suku Bugis}

Suku Bugis merupakan kelompok etnik dengan wilayah asal Sulawesi Selatan. Penciri utama kelompok etnik ini adalah bahasa dan adat-istiadat, sehingga pendatang Melayu dan Minangkabau yang merantau ke Sulawesi sejak abad ke-15 sebagai tenaga administrasi dan pedagang di Kerajaan Gowa dan telah terakulturasi, juga dikategorikan sebagai orang Bugis. ${ }^{6}$

Berdasarkan sensus penduduk Indonesia tahun 2000, populasi orang Bugis sebanyak sekitar enam juta jiwa. Kini orang-orang Bugis menyebar pula di berbagai provinsi Indonesia, seperti Sulawesi Tenggara, Sulawesi Tengah, Papua, DKI Jakarta, Kalimantan Timur, Kalimantan Selatan, Jambi, Riau, dan Kepulauan Riau. Disamping ituorang-orang Bugis juga banyak ditemukan di Malaysia dan Singapura yang telah beranak pinak dan keturunannya telah menjadi bagian dari negara tersebut. Karena jiwa perantau dari masyarakat Bugis, maka orang-orang Bugis sangat banyak yang pergi merantau ke mancanegara.

\footnotetext{
${ }^{6}$ Badan Pusat Statistik 2011, Kewarganegaraan, Suku Bangsa, Agama dan Bahasa Sehari-hari Penduduk Indonesia Hasil Sensus Penduduk. 2010. ISBN 9789790644175.
} 
Bugis adalah suku yang tergolong ke dalam suku-suku Melayu Deutero. Masuk ke Nusantara setelah gelombang migrasi pertama dari daratan Asia tepatnya Yunan. Kata "Bugis" berasal dari kata To Ugi, yang berarti orang Bugis. Penamaan "ugi" merujuk pada raja pertama kerajaan Cina yang terdapat di Pammana, Kabupaten Wajo saat ini, yaitu La Sattumpugi. Ketika rakyat La Sattumpugi menamakan dirinya, maka mereka merujuk pada raja mereka. Mereka menjuluki dirinya sebagai To Ugi atau orang-orang atau pengikut dari La Sattumpugi. La Sattumpugi adalah ayah dari We Cudai dan bersaudara dengan Batara Lattu, ayah dari Sawerigading. Sawerigading sendiri adalah suami dari We Cudai dan melahirkan beberapa anak termasuk La Galigo yang membuat karya sastra terbesar di dunia dengan jumlah kurang lebih 9000 halaman folio. Sawerigading Opunna Ware (Yang dipertuan di Ware) adalah kisah yang tertuang dalam karya sastra I La Galigo dalam tradisi masyarakat Bugis. Kisah Sawerigading juga dikenal dalam tradisi masyarakat Luwuk, Kaili, Gorontalo dan beberapa tradisi lain di Sulawesi seperti Buton.

Suku Bugis dikenal sebagai suku yang menyebar luas ke berbagai daerah di Indonesia. Orang Bugis melakukan perantauan besar-besaran di kawasan Nusantara sejak abad ke-17 Masehi. Koloni-koloni suku Bugis ditemukan di Kalimantan Timur, Kalimantan Selatan, Pontianak, Johor, dan Semenanjung Melayu. Suku Bugis diperanau bayak menekuni pekerjaan sebagai perkebunan, persawahan dan perikanan.

\section{Metode}

Jenis penelitian yang digunakan adalah deskriptif kualitatif yaitu suatu metode penelitian yang dilakukan dengan membuat gambaran atau deskripsi tentang suatu keadaan secara objektif. penelitian kualitatif bersifat studi kasus yang bertujuan untuk menggambarkan, meringkas berbagai kondisi, berbagai situasi atau berbagai fenomena realitas sosial yang ada dalam masyarakat yang menjadi objek penelitian yang berupaya menarik realitas itu ke permukaan sebagi suatu ciri, karekter, sifat, model tanda atau gambaran tentang kondisi, situasi atau fenomena tertentu. Penelitian kualitatif bertujuan untuk memahami realitas sosial, yaitu melihat subjek penelitian dari apa adanya, bukan dari apa yang seharusnya. ${ }^{8}$

Teknik pengumpulan data dalam penelitian ini dilakukan dengan metode sebagai berikut:

1. Observasi

Observasi atau pengamatan adalah metode pengumpulan data yang digunakan untuk menghimpun data penelitian melalui pengamatan dengan menggunakan pancaindra.

\section{Wawancara}

7 Hendraswati, Dalle, J., dan Jamalie, Z. (2017). Diaspora dan Ketahanan Budaya Orang Bugis di Pagatan Tanah Bumbu (PDF). Yogyakarta: Penerbit Kepel Press. 2-3. ISBN 978-602-356-197-1.

${ }^{8}$ Bungin, Burhanuddin. 2008. Sosiologi Komunikasi. Jakarta: Prenada Media Group. 68 
Wawancara adalah percakapan dengan maksud tertentu. Teknik wawancara yang digunakan dalam penelitian ini adalah wawancara berpedoman atau terikat, serta wawancara bebas dan mendalam (indept interview).

3. Dokumentasi

Dokumentasi ini digunakan untu memperuat data-data yang diperoleh dari metode yang digunakan sebelumnya. Metode ini dilakukan untuk pengumpulan data sekunder yang sudah tertulis maupun melalui pengambilan gambar aktivitas dilokasi berupa arsip atau dokumen dan foto secara optimal yang memberikan penjelasan dan keterangan lengkap mengenai perihal yang diteliti,

Data hasil penelitian dari informan yang terkumpul baik hasil wawancara, observasi maupun dokumentasi selanjutnya dianalisis. Menurut Miles dan Huberman dalam Moleong (2002: 295) analisis data kualitatif terdiri atas; reduksi data, penyajian data dan penarikan kesimpulan/verifikasi. (1) Reduksi data yaitu, proses pemilihan, pemusatan perhatian pada penyederhanaan, pengabstrakan, dan transformasi data kasar yang muncul dari catatan tertulis dilapangan yang berhubungan dengan permasalahan penelitian. (2) Penyajian data, yaitu sekumpulan data informasi tersusun yang member kemungkinan adanya penakrikan kesimpulan dan pengambilan tindakan secara logis dan sistematis sesuai dengan teori yang ada hubungannya dengan permasalahan penelitian. (3) Melalui penyajian data tersebut maka data tergonisir, tersususun dalam pola hubungan sehingga dapat menarik kesimpulan/verifikasi.

\section{HASIL PENELITIAN}

\section{Alasan Masyarakat Suku Bugis Kelurahan Kabonena Kecamatan Ulujadi Kota Palu Melakukan Tradisi Mabbaca Doang}

Sesuai dengan hasil penelitian yang telah digambarkan pada bagian sebelumnya. Maka peneliti akan membahas data-data yang telah diperoleh di lokasi penelitian dan dikaitkan dengan kajian kepustakaan atau referensi dalam penelitian ini. Berikut akan dipaparkan lebih jelas dari hasil penelitian yang didapatkan oleh peneliti:

Pada hakikatnya manusia diciptakan sebagai makhluk yang paling sempurna melebihiciptaan Tuhan lainnya, diberikan akal dan pikiran serta hawa nafsu agar dapat digunakan untuk kebaikan mereka masing-masing sehingga mampu bertahan hidup di bumi ini. Perbedaan tempat tinggal membuat kebiasaan, adat, serta kepribadian setiap individu sehingga membentuk sebuah kebudayaan yang berbeda seperti halnya di Masyarakat Suku Bugis Kelurahan Kabonena Kecamatan Ulujadi Kota Palu kebiasaan yang mereka sering lakukan adalah mabbaca doang. Doa yang dipanjatkan dengan niat semata-mata karena Allah SWT.

Hal ini merupakan salah satu tradisi yang sering dilakukan masyarakat setempat dengan tujuan yaitu mengucap syukur kepada Allah SWT atas keberkahan dan rejeki yang telah mereka dapatkan. Tradisi merupakan hasil cipta serta karya manusia yang diwariskan secara turun temurun, sesuatu yang diwariskan tidaklah berarti harus diterima, dihargai, diasimiliasi atau disimpan sampai mati kecuali hal tersebut membawa pengaruh dan tujuan yang positif. Ditemukan berbagai alasan 
masyarakat desa Pasaka melakukan baca doang ini antara lain yaitu: a) mabbaca doang merupakan warisan leluhur dari nenek moyang, b) terdapat keyakinan dalam diri masyarakat desa Pasaka apabila tidak melakukannya maka akan terkena musibah.

1) Mabbaca doang merupakan warisan leluhur dari nenek moyang

Mabbaca doang dilakukan pada saat-saat tertentu oleh masyarakat Desa Pasaka misalnya pada saat memasuki bulan suci ramadhan, setelah lebaran, sebelum turun ke sawah ataupun setelah mengambil hasil panen, setelah membeli kendaraan, panen buah. Sebelum kegiatan tersebut dilaksanakan, orang yang bersangkutan terlebih dahulu menyiapkan beberapa hal-hal pokok seperti hidangan makanan, dupa, dan yang terpenting adalah pabbaca (orang yang dituakan, kepala suku, atau orang-orang yang paham tentang bacaan-bacaan yang akan dibacakan nantinya).

Pemaparan informan menekankan bahwa prosesi mabbaca doang ini sudah menjadi kebiasaan yang wajib yang mereka harus lakukan meskipun tidak ada hukum yang mengatur bahwa kegiatan tersebut wajib hukumnya. Tradisi yang dimiliki masyarakat bertujuan agar membuat hidup manusia kaya akan budaya dan nilai bersejarah. Selain itu, tradisi juga akan menciptakan kehidupan yang harmonis. ${ }^{5}$ Kehidupan yang harmonis ditunjukkan pada saat melakukan mabbaca doang, ada sejumlah makanan yang disajikan kemudian memanggil sanak saudara serta tetangga untuk menyantap hidangan secara bersama-sama. Hal tersebut diyakini mampu memperarat tali silaturahmi.

Pelaksanaan mabbaca doang dulu dan sekarang sudah tentu berbeda seiring dengan perubahan sosial dan perkembangan zaman. Meskipun demikian, tradisi ini masih tetap saja dilaksanakan dan diterima secara baik oleh masyarakat setempat. Seperti misalnya pada zaman dulu ketika masyarakat ingin mabbaca doang mereka berkumpul pada satu tempat namanya saoraja (rumah besar). Sebab pada waktu itu masih menganut sistem kekerajaan, semua kegiatan dalam suatu wilayah harus seizin raja. Disamping itu rumah warga belum layak ditempati untuk melakukan prosesi tersebut karena ruangannya kecil.

Tetapi saat ini hal itu sudah bergeser, sekarang warga sudah mempunyai rumah dengan ruangan yang cukup luas dan sistem kekerajaan pun sudah berubah maka pelaksanaan mabbaca doang sudah bisa dilakukan di rumah masing-masing namun tetap mengumpulkan warga atau tetangga untuk datang menyantap hidangan yang telah disiapkan. Prosesi dalam pelaksanaan mabbaca doang ini tidaklah rumit, sebab yang paling penting adalah pabbacanya (orang yang membacakan doa-doa berisi rasa syukur terhadap Tuhan Yang Maha Kuasa) yang kedua adalah dupa dan kemenyan. Karena prosesinya yang terbilang simpel, maka dari itu tradisi ini masih dipertahankan sampai detik ini.

Berbagai macam jenis mabbaca doang yang telah diwariskan seperti yang telah dipaparkan di atas, yang paling sering dilakukan adalah mabbaca doang ketika bulan suci ramadhan tiba, hal ini berkaitan dengan kepercayaan yang dianut adalah Islam. Ketika ingin turun ke sawah serta setelah panen dikaitkan dengan letak kondisi geografis 
Masyarakat Suku Bugis Kelurahan Kabonena Kecamatan Ulujadi Kota Palu yang berada pada daerah persawahan, disamping itu mata pencaharian utama masyarakat setempat adalah bertani. Yang warga lakukan adalah tidak lain menggambarkan rasa syukur mereka kepada sang pencipta atas sesuatu yang telah merekadapatkan.

Jika dikaitkan dengan agama Islam mereka beranggapan bahwa hal tersebut sama sekali tidak bertentangan jika niatnya karena Allah. Dalam kasus kepercayaan berbagai agen manusia, dugaan akan keyakinan melibatakan "kebaikan" (penghargaan) atau cinta kasih. Kepercayaan merupakan "kecenderungan perilaku" tertentu yang dapat mengurangi resiko yang muncul dan perilakunya. Kepercayaan selalu mengandung konotasi keyakinan ditengah-tengah berbagai akibat yang serba mungkin. ${ }^{6}$ Terdapat keyakinan dalam diri masyarakat Desa Pasaka apabila tidak melakukan tradisi tersebut maka akan terkena musibah.

Kebiasaan-kebiasaan tersebut telah mendarah daging dan sulit untuk dilepaskan meskipun hantaman dari modernisasi terus berlangsung, hal tersebut tidak mampu mematikan kepercayaan masyarakat terhadap hal-hal demikian, meskipun sudah banyak yang pemikirannya telah maju tidak terkecuali di pelosok desa sekalipun namun tidak dapat dipungkiri masih banyak pula masyarakat yang masih mempertahankannya. Mempertahankan warisan leluhur merupakan tanggung jawab dari generasi berikutnya. Maka dari itu masyarakat Desa Pasaka masih melakukan tradisi mabbaca doang ini.

Warga yang pernah berucap atau bernasar mengatakan akan mabbaca doangsetelah melakukan sesuatu sebagai pengucap rasa syukur namun tidak dilaksanakan maka diyakini akan tertimpa musibah seperti sakit-sakitan. Di dalam Masyarakat Suku Bugis Kelurahan Kabonena Kecamatan Ulujadi Kota Palu seiring dengan perkembangan zaman sudah mempunyai pemikiran yang berbeda-beda pula. Meskipun ada beberapa kalangan yang tidak sepaham dengan kegiatan ini, tetapi kehidupan masyarakat di Desa Pasaka berdasarkan dari hasil observasi dan pembuktian data dari badan pusat statistik tentang kriminalitas di daerah tersebut sampai saat ini belum ditemukan, itu artinya menunjukkan bahwa mereka hidup dengan kondisi yang harmonis.

Mereka bukannya tidak mau berkonflik, namun Masyarakat Suku Bugis Kelurahan Kabonena Kecamatan Ulujadi Kota Palu memiliki rasa sipakatau (saling menghargai) dalam kehidupan. Jika dikaitkan dengan teori fungsionalisme struktural, maka functionalist (para penganut pendekatan fungsional) melihat masyarakat dan lembagalembaga sosial sebagai suatu sistem yang seluruh bagiannya saling tergantung satu sama lain dan bekerja sama menciptakan keseimbangan (equilibrium). Mereka memang tidak menolak keberadaan konflik di dalam masyarakat, akan tetapi mereka percaya bahwa masyarakat itu sendiri akan mengembangkan mekanisme yang dapat mengontrol konflik yang timbul. Inilah yang menjadi pusat perhatian analisis bagi kalangan fungsionalis.

Menurut teori ini, masyarakat merupakan suatu sistem sosial yang terdiri atas bagian-bagian atau elemen yang saling berkaitan dan saling menyatu dalam kesimbangan.Asumsi dasarnya adalah setiap sturktur dalam sistem fungsional terhadap 
yang lain.Artinya, struktur yang ada dalam masyarakat seperti kebiasaan-kebiasan yang sering dilakukakan oleh masayrakat setempat seperti mabbaca doang fungsional terhadap struktur sosial yang lainya bahkan tidak mengganggu ketertiban sosial, maka timbullah situasi equilibrium (seimbang). Karena dalam teori struktural fungsional ketika konflik muncul, maka masyarakat akan kembali dalam kondisi yang seimbang. Sebaliknya, kalau tidak fungsional maka struktur itu tidak akan ada atau akan hilang dengan sendirinya.

\section{Makna Mabbaca Doang Pada Masyarakat Suku Bugis Kelurahan Kabonena Kecamatan Ulujadi Kota Palu.}

Kebudayaan itu bukan saja merupakan seni dalam hidup, tetapi juga benda-benda yang terdapat di sekeliling manusia yang dibuat oleh manusia. Itulah sebabnya kemudian kebudayaan diartikan sebagai cara hidup yang dikembangkan oleh sebuah masyarakat guna memenuhi keperluan dasarnya untuk dapat bertahan hidup, meneruskan keturunan dan mengatur pengalaman sosialnya. Kebudayaan adalah ekspresi eksistensi manusia di dunia. Pada kebudayaan, manusia menampakkan jejak-jejak dalam panggung sejarah di zaman modern yang memungkinkan adanya perubahan dalam setiap aspek kehidupan, termasukperubahan dalam aspek budaya yaitu dari budaya tradisional menjadi budaya modern.

Setiap kebudayaan yang diciptakan oleh manusia tentunya mengandung makna yang tersirat di dalamnya. Makna tradisi mabbaca doang pada Masyarakat Suku Bugis Kelurahan Kabonena Kecamatan Ulujadi Kota Palu yakni :

1. Sebagai bentuk rasa syukur kepada Tuhan

Masyarakat Suku Bugis Kelurahan Kabonena Kecamatan Ulujadi Kota Palu pada kenyatannya tidak bisa lepas dari kebiasaan- kebiasaan yang menjadi budaya mereka sejak lahir. Tradisi ini masih nampak dilakukan dengan sangat baik dari berbagai lapisan masyarakat. Awal mula dilakukannya mabbaca doang yaitu sebelum masyarakat mengenal ajaran Agama yang sah (Islam), karena keyakinan masyarakat bugis dahulu itu sangat kental dengan pengaruh kepercayaan- kepercayaan seperti kepercayaan terhadap roh, dewa-dewa, matahari, bulan, bintang, pohon dan benda-benda hidup atau mati lainnya.

Pada saat Islam sudah mulai mempengaruhi masyarakat, orang yang menyebarkan agama islam tersebut tidak memaksa masyarakat untuk meninggalkan kebiasaan mereka tetapi di akulturasikan sehingga budaya lama tidak hilang dengan adanya budaya baru tersebut. Sehingga seiring dengan perkembangan zaman dan secara turun temurun di yakini pula oleh generasi kegenerasi turunannya. Tentu ada suatu bentuk ritual dalam suatu kelompok masyarakat seperti halnya mabbaca doang, orang melakukan tradisi tersebut sebagai bentuk rasa syukur dan pengingat mereka terhadap sang pencipta, agar merekaselalu mengingat bahwa ada yang menjadi penyebab dari segala sesuatu yang terjadi di dunia ini termasuk dengan berhasil atau tidaknya tanaman yang mereka tanam. Mereka menyakini adanya hal-hal yang gaib, yakin adanya makhluk lain selain manusia makanya warga Masyarakat Suku Bugis Kelurahan Kabonena 
Kecamatan Ulujadi Kota Palu merasa perlu menjaga hubungan dengan segala makhluk ciptaan Tuhan.

Agama dan perilaku keagamaan tumbuh dan berkembang dari adanya rasa ketergantungan manusia terhadap kekuatan gaib yang mereka rasakan sebagai sumber kehidupan mereka. Mereka harus berkomunikasi untuk memohon bantuan dan pertolongan kepada kekuatan gaib tersebut, agar mendapatkan kehidupan yang aman, selamat dan sejahtera. Dengan demikian, rasa kepercayaan, agama dan perilaku keagamaan (agama dan kehidupan beragama) merupakan pembawaan dari kehidupan manusia, atau dengan istilah lain merupakan "fitrah" manusia". Masyarakat meyakini bahwa adanya hal-hal yang gaib dalam hidup sehingga kita akan percaya pula akan adanya Tuhan. Budaya yang tumbuh dan berkembang di masyarakat manusia tidak lepas dari nilai-nilai yang telah dibangunnya sendiri, berbagai bentuk nilai-nilai budaya itu merupakan konsep-konsep yang hidup di dalam alam pikiran sebagian besar dari warga suatu masyarakat mengenai apa yang mereka anggap bernilai, berharga dan penting dalamhidup, sehingga dapat menjadi suatu pedoman yang memberi arah dan orientasi kepada kehidupan pada warga masyarakatnya.

\section{Penolak bala}

Tingkat pemikiran manusia yang semakin modern ternyata tidak mampu untuk menghilangkan pemikiran teologis. Pemikiran teologis menekankan pada keyakinan bahwa kekuatan adikodrati, tokoh agama dan keteladanan kemanusiaan menjadi dasar segala sesuatu. Dunia social dan alam fisik khususnya di pandang sebagai ciptaan Tuhan. Pemikiran teologis sampai saat ini tetap hidup dan dipandang penting karena setiap tahap baru sisa-sisa tahap lama yang masih tetap hidup walaupun tidak dominan. Kebutuhan dan keinginan individu akan mempengaruhi persepsi sesorang terhadap suatu objek. Hal ini tidak terlepas dari aspek subjektivitas seseorang, di mana apabila seseorang mengharapkan sesuatu dari orang lain maka apabila diminta pandangannya, maka mereka senantiasa bersifat menyenangkan orang lain demi memenuhi kebutuhan-kebutuhannya. ${ }^{8}$ Masyarakat desa Pasaka pun seperti itu, dengan keyakinan yang mereka miliki dengan balasan yang mereka dapat ketika melakukan dan tidak melakukan tradisi yang sudah menjadi kebiasaan mereka secara turun temurun, maka menurut mereka mabbaca doang tersebut tidaklah mengganggu ataupun menentang nilai-nilai dalam agama Islam.

Makna dari pelaksanaan mabbaca doang sebagai penolak bala (penangkal bencana) dengan membaca bacaan-bacaan tertentu yang mempunyai maksud menolak kejadian-kejadian yang tidak diinginkan oleh masyarakat di desa Pasaka semisal pada saatmusim padi tiba, padi yang di tanam itu menghasilkan buah yang banyak, terhindar dari hama, kualitas biji padinya bagus. Atau pada saat ramadhan tiba mabbaca doang agar diberikan kesehatan sehingga mampu menjalani puasa dengan baik pula. Dengan melakukan serangkaian kegiatan mabbaca doang menyediakan berbagai macam makanan seperti songkolo putih dan hitam, pisang, udang, ayam sebagai sajian untuk para tetangga yang datang untuk disantap bersama. 


\section{Fungsi Mabbaca Doang pada Masyarakat Suku Bugis Kelurahan Kabonena Kecamatan Ulujadi Kota Palu}

Mengenai masa prasejarah aspek-aspek keagamaan tertentu hanya dapat didekati melalui interpretasi atas keterkaitan antar benda didalam suatu situs penggalian maupun melalui analogi dengan praktik kegamaan pada tradisi tertentu. Inti kepercayaan suatu religi juga dapat menyangkut konsep mengenai kosmos (yang sering dijumpai pula penyejaran kosmos makro dan mikro), baik mengenai struktur maupun proses kejadiannya. Aspek lain yang sering dapat dikenali adalah pandangan mengenai hidup sesudah mati, atau disamping alam kehidupan manusia didunia ini. Tradisi mengalami perubahan, perubahan kuantitatifnya terlihat dalam jumlah penganut atau pendukungnya. Sebagian masyarakat dapat diikut sertakan pada tradisi tertentu yang kemudian akan mempengaruhi masyarakat secara keseluruhan. Dalam ceramah-ceramah Robertson Smith mengemukakan tiga gagasan penting yang menambah pengertian kita mengenai azas-azas religi dan agama pada umumnyayang berkaitan dengan fungsi tradisi upacara bersaji dalam hal ini mabbaca doang antara Sebagai perwujudan religi.

Kehidupan manusia tentunya pernah merasakan hubungan dengan kekuatan adikodrati yang kemudian menggetarkan seluruh sendi emosinya. Religi dari bahasa latin berasal dari kata religare dan relegare. Religare memiliki makna "suatu perbuatan yang memperhatikan kesungguh-sungguhan dalam melakukannya". Sedangkan relegare memiliki makna perbuatan bersama dalam ikatan saling mengasihi". Kedua istilah tersebut memiliki corak individial dan sosial dalam suatu perbuatan yang religius. Gagasan yang pertama mengenai soal bahwa di samping keyakinan dan doktrin, sistem upacara seperti mabbaca doang juga merupakan suatu perwujudan dari religi atau agama. Hal yang menarik perhatian Roberthson Smith adalah bahwa dalam banyak agama upacaranya itu tetap, tetapi latar belakang, keyakinan, maksud atau doktrinnya berubah.

Sistem religi selalu berkaitan dengan upacara keagamaan, banyak cara yang dilakukan manusia untuk menginterpretasikan sistem keyakinan yang mereka miliki, informasi yang diberikan oleh informan diatas menggambarkan bahwa perwujudan dari rasa syukur yang mereka rasakan itu dengan mabbaca doang, mereka merasa perlu melakukan pembuktian atas apa yang mereka rasakan dari apa yang mereka yakini. Di daerah lain mungkin dilaksanakan juga kebiasaan seperti ini tetapi tata cara pelaksanaan yang berbeda, misalnya makanan yang disajikan berbeda namun fungsinya sama yaitu sebagai bentuk religi. Sistem keyakinan merupakan suatu yang sakral bagi masyarakat Desa Pasaka yang mempertahankan nilai-nilai yang terkandung di dalam tradisi mabbaca doang. Munculnya kepercayaan pada satu Tuhan yang dianggap meliputi segala hal di alam semesta ini menjadikan manusia menciptakan berbagai macam tradisi dari hasil kepercayaan tersebut yang mengakibatkan perbedaan kebudayaan.

Sebagai landasan Masyarakat Suku Bugis Kelurahan Kabonena Kecamatan Ulujadi Kota Palu bertindak dalam melakukan sesuatu hal berdasarkan pemahaman 
atau kepercayaan kepada Tuhan. Mereka yakin bahwa apa yang mereka lakukan berdasarkan niat karena Allah, dengan menghargai segala ciptaan Tuhan baik yang terlihat maupun tidak, sebab jika tidak mempercayai hal-hal yang gaib, berarti tidak ada keyakinan dalam dirinya tentang keberadaan Tuhan. Proses islamisasi di Kabupaten Bone ditanggapi dengan baik oleh masyarakat, sebab dalam penerapannya tidak langsung menghilangkan kebiasaan-kebiasaan yang telah tercipta sejak lama, tetapi pada setiap pelaksanaan upacara yang berhubungan dengan kebiasaankebiasaan masyarakat dikaitkan dengan islam. Jadi setiap upacara senantiasa ditempatkan sifat islami yang berdampingan dengan budaya masyarakat setempat.

a. Mengintensifikasikan solidaritas masyarakat

Gagasan yang kedua adalah bahwa upacara religi atau agama, yang biasanya dilaksanakan oleh banyak warga masyarakat pemeluk religi atau agama yang bersangkutan bersama-sama mempunyai fungsi sosial untuk mengintensifikasikan solidaritas masyarakat. Para pemeluk suatu religi atau agama menjalankan kewajiban mereka untuk melakukan upacara-upacara yang berkaitan dengan keyakinan mereka dengan sungguh-sungguh, tetapi tidak sedikit pula yang hanya melakukannya setengahsetengah saja. Motivasi mereka tidak terutama untuk berbakti kepada dewa atau Tuhannya, atau untuk mengalami kepuaasan keagamaan secara pribadi, tetapi juga karenamereka menganggap bahwa melakukan upacara adalah suatu kewajiban

Meskipun ada beberapa diantara warga masyarakat yang sudah tidak menjalankan upacara-upacara tersebut tetapi mereka tidak saling menjatuhkan satu sama lain, melainkan mereka masih saling menghargai. Prosesi mabbaca doang dulu dilakukan pada satu tempat namanya saoraja (rumah besar) semua warga membawa makanan yang telah mereka siapkan di rumah masing-masing kemudian di bawa ke saoraja tersebut. Partisipasi yang ditunjukkan oleh masyarakat setempat masih terlihat, silaturahmi terjalin baik dengan adanya kegiatan-kegiatan dalam pelaksanaan upacara-upacara adat yang masih dipegang teguh. Sebelum melakukan prosesi mabbaca doang, dilakukan terlebih dahulu perundingan atau mereka tudang sipulung (berunding). Seiring globalisasi dan modernisasi serta perubahan sosial yang terjadi, prosesi mabbaca doang sudah mulai bergeser di desa Pasaka, dulunya warga setempat berkumpul pada satu titik namun sekarang sudah bisa dilakukan di masing-masing rumah.

Hal tersebut tidak memutuskan tali silaturahmi antara warga masyarakat setempat sebab pada saat mabbaca doang, yang bersangkutan tetap memanggil para tetangga dan sanak saudara dengan tujuan ikut mengucap syukur atas berkah yang didapatkan. Karena sebuah tradisi merupakan simbol identitas kolektif yang meyakinkan serta memperkuat loyalitas primordial terhadap komunitas.

\section{KESIMPULAN}

Tradisi Mabbaca doang Masyarakat Suku Bugis Kelurahan Kabonena Kecamatan Ulujadi Kota Palu cukup menarik untuk dikaji, pada kesempatan ini peneliti dapat menyimpulkan bahwa : 1) Masyarakat Suku Bugis Kelurahan Kabonena 
Kecamatan Ulujadi Kota Palu melakukan tradisi mabbaca doang disebabkan yang pertama karena pemikiran masyarakat di daerah tersebut masih terbilang tradisional dan memegang nilai-nilai luhur warisan nenek moyang, mereka meyakini bahwa dengan melakukan kebiasaan tersebut,akan mendatangkan kebaikan dalam kehidupan mereka serta keyakinan melibatakan "kebaikan" (penghargaan) atau cinta kasih. Yang kedua yaitu terdapat keyakinan dalam diri masyarakat desa Pasaka apabila tidak melakukan tradisi tersebut maka akan terkena musibah, Kebiasaan-kebiasaan tersebut telah mendarah daging dan sulit untuk dilepaskan meskipun hantaman dari modernisasi terus berlangsung, hal tersebut tidak mampu mematikan kepercayaan masyarakat terhadap hal-hal demikian sebab mempertahankan nilai-nilai luhur merupakan tanggung jawab bersama. 2) Makna mabbaca doang bagi Masyarakat Suku Bugis Kelurahan Kabonena Kecamatan Ulujadi Kota Palu yaitu pertama Sebagai bentuk rasa syukur kepada Tuhan, tradisi ini masih nampak dilakukan dengan sangat baik dari berbagai lapisan masyarakat Agama dan perilaku keagamaan tumbuh dan berkembang dari adanya rasa ketergantungan manusia terhadap kekuatan gaib yang mereka rasakan sebagai sumber kehidupan mereka. Mereka harus berkomunikasi untuk memohon bantuan dan pertolongan kepada kekuatan gaib tersebut, agar mendapatkan kehidupan yang aman, selamat dan sejahtera. Selanjutnya adalah pemaknaan dalam penolak bala (penangkal bencana), adanya kebutuhan dan keinginan individu akan mempengaruhi persepsi sesorang terhadap suatu objek. Manusia senantiasa ingin hidup aman maka mereka senantiasa bersifat menyenangkan orang lain maupunn hal-hal yang gaib demi memenuhi kebutuhan-kebutuhannya. 3) Fungsi mabbaca doang bagi Masyarakat Suku Bugis Kelurahan Kabonena Kecamatan Ulujadi Kota Palu yaitu sebagai perwujudan religi, berhubungan dengan keyakinan dan doktrin, sistem upacara seperti mabbaca doang juga merupakan suatu perwujudan dari religi atau agama meskipun dalam banyak agama upacaranya itu tetap, tetapi latar belakang, keyakinan, maksud atau doktrinnya berubah. Selain sebagai perwujudan religi, fungsi lain mabbaca doang adalah mengintensifikasikan solidaritas masyarakat dan menjaga hubungan dengan sang pencipta. Para pemeluk suatu religi atau agama memang ada menjalankan kewajiban mereka untuk melakukan upacara itu dengan sungguh-sungguh, tetapi tidak sedikit pula yang hanya melakukannya setengahsetengah saja. Motivasi mereka bukan untuk berbakti kepada Tuhannya, atau untuk mengalami kepuaasan keagamaan secara pribadi, tetapi juga karena mereka menganggap bahwa melakukan upacara adalah suatu kewajiban sosial.

\section{Referensi}

Damsar \& Indrayani. 2009. Pengantar Sosiologi Ekonomi. Jakarta: Prenada Media. Emzir. 2011. Metodologi Penelitian Kualitatif Analisis Data. Cetakan Ke dua. Jakarta:Rajawali Pers

Idrus, Muhammad, 2009. Metode Penelitian Ilmu Sosial pendekatan kualitatif dan kuantitatif. 
Jakarta: Erlangga

Muli, John. 2012. Kajian Antropologi Pada Sistem Religi. Malang.

Natali Juli, "Hakikat Kebudayaan Nasional", Blog Natali Yuli. http: //Pendidikan.blogspot.com/2013/11 / hakikat-kebudayaan-nasionaldalam.html.

Omi Sastra, "Tradisi Pantauan Pengantin Di Desa Alam Lama Kecamatan Kota Agung Kabupaten Labat", skripsi, (Palembang: Fakultas Adab dan Humaniora, UIN Raden Fatah Palembang), 2017 Hal. 1

IKIP BU Malang Moleong Lexy J. M.A.2016. Metodologi Penelitian kualitatif.

Bandung: P'T Remaja Rosdakarya.

Sugiyono .2010. Metode Penelitian Pendidikan; Pendekatan kualitati kuantitatif dan R\&D. Bandung: Alfabeta.

Sedyawati, Edy. 2012. Budaya Indonesia: Kajian Arkeologi, Seni, dan Sejarah. Jakarta:Rajawali Press.

Syukri, Muhammad, dkk. 2015. Ilmu Sosial Budaya Dasar. Cetakan Pertama. Jakarta: PT RajaGrafindo Persada. 